\title{
Sobre Traduções Comentadas On Translations with Commentaries
}

Tendo como um de seus objetivos estabelecer uma ponte entre as especulações teóricas sobre a tradução e sua prática, Scientia Traductionis inaugura aqui sua seção ‘Traduções Comentadas’!

Uma definição operativa de 'tradução comentada' é ofertada por Williams \& Chesterman (2002, p.7) ${ }^{1}$ :

A tradução com comentário (ou tradução comentada) é uma forma de pesquisa introspectiva e retrospectiva em que o tradutor traduz um texto e, ao mesmo tempo, escreve um comentário a respeito de seu processo de tradução. Esse comentário inclui alguma discussão a respeito do encargo de tradução, uma análise de aspectos do texto fonte e justificativas bem fundamentadas dos tipos de soluções a que se chegou para tipos específicos de problemas de tradução. ${ }^{2}$

No universo editorial dos Estudos da Tradução, a relevância deste tipo de texto tem um precedente na revista galega 'Viceversa', criada em 1995 pela Universidade de Vigo, Espanha. De maneira similar ao entendimento desta Scientia Traductionis, em sua seção 'traducións xustificadas' “os tradutores reflexionan sobre o proceso da tradución, partindo do seu propio labor."3 Trata-se, portanto, aqui como lá, de um espaço em
Having the establishment of a bridge between theoretical speculations on translation and its practice as one of its goals, Scientia Traductionis inaugurates its 'Translations with Commentaries' section!

An operative definition of 'translation with commentary' is offered by Williams \& Chesterman (2002, p.7):

A translation with commentary (or annotated translation) is a form of introspective and retrospective research where you yourself translate a text and, at the same time, write a commentary on your own translation process. This commentary will include some discussion of the translation assignment, an analysis of aspects of the source text, and reasoned justifications of the kinds of solutions you arrived at for particular kinds of translation problems. ${ }^{4}$

In the editorial circles of Translation Studies, the relevance of this kind of text has a precedent in the Galician journal ' $\mathrm{Vi}$ ceversa', created in 1995, by Universidade de Vigo, Spain. Similarly to the understanding of this Scientia Traductionis, in that journal's section entitled 'traducións xustificadas' "translators reflect on the process of translation based on their own activity" 5 Thus, here and there, this is a

\footnotetext{
${ }^{1}$ WILLIAMS, J. \& CHESTERMAN, A. The Map. A Begginer's Guide to Doing Research in Translation Studies. Manchester, UK: St. Jerome, 2002.

2 Tradução nossa.

${ }^{3}$ http://webs.uvigo.es/webatg/viceversa/viceversa.htm

${ }^{4}$ WILLIAMS, J. \& CHESTERMAN, A. The Map. A Begginer's Guide to Doing Research in Translation Studies. Manchester, UK: St. Jerome, 2002.

${ }^{5}$ http://webs.uvigo.es/webatg/viceversa/viceversa.htm : "os tradutores reflexionan sobre o proceso da tradución, partindo do seu propio labor.”
} 
que o executor da tradução expõe sua reflexão sobre a tarefa empreendida.

É nossa esperança que esta seção do periódico proporcione ao público escritor e leitor uma instância frutífera para o enriquecimento da cultura tradutória e dos Estudos da Tradução.

Mauri Furlan

Gustavo Althoff

Editores space in which the translation practitioner reveals his or her reflection on the task undertaken.

It is our hope that this section of the journal affords its writers and readers a fruitful opportunity for the enrichment of translatorial culture and Translation Studies.

Mauri Furlan

Gustavo Althoff

Editors 